\title{
ANALYSIS OF ALTERNATIVE SELECTION FOR VERTICAL CLEARANCE DESIGN UNDER TABALONG BRIDGE OF PT ADARO INDONESIA
}

\author{
Diean Oktavian Regar ${ }^{1}$, Aqli Mursadin ${ }^{1}$ \\ ${ }^{1}$ Faculty of Engineering, Lambung Mangkurat University, J1. A. Yani Km. 35.8, South \\ Borneo, Indonesia \\ e-mail: deanregar@gmail.com
}

\begin{abstract}
PT Adaro Indonesia is trying to adjust a vertical clearance under Tabalong Bridge 1 (unloaded) and Tabalong Bridge 2 (loaded) because the existing conditions still apply a minimum vertical clearance of $4 \mathrm{~m}$. It should be in accordance with latest Regulation of the Minister of Public Works No. 19/PRT/M/2011 that for vertical clearance above national road at least $5.1 \mathrm{~m}$. This specification has not been met by the national road under the Tabalong $1 \& 2$ Bridges because both bridges were built in the 90s. Therefore we need an engineering technique to overcome this. There are 2 alternative designs, namely lowering the elevation of the national road and increasing the elevation of the bridge's upper structure to mitigate oversized vehicles so as not to hit the lower structure of the Tabalong bridge. In determining the selection of the best alternative designs in this research is based on two (2) things, nonfinancial criteria with Analytical Hierarchy Process (AHP) and financial criteria with Life Cycle Cost Analysis (LCCA)/Benefit Cost Ratio (BCR) method. This study uses a survey method by distributing questionnaires and interviews as a means of collecting primary data. In addition, previous research and consultant DED documents were used as a means of collecting secondary data. The AHP method is used to process primary data to produce a decision from a non-financial aspect. While the LCC/BCR method is used to process secondary data to produce a decision from the financial aspect. The results of the AHP analysis obtained that the synthesis value of the decision the option of lowering national roads was $85 \%$ and the bridge lifting option was $15 \%$ and the consistency ratio (CR) was $0.05<0.1$. The consistency ratio below 0.1 shows that the questionnaire data from the respondents are consistent. The results of the analysis of Life Cycle Cost (LCC) obtained the option of lowering national roads where the LCC value is Rp. 44,877,651,669.27 more economical than the bridge lifting option. Then the results of the Benefit Cost Ratio (BCR) analysis obtained the option of lowering national roads with a BCR value of $2.33>1$ and NPV = Rp. 43,442,264,804.34 >1 means that the option lowering national roads is feasible. While the bridge lifting option is obtained by analyzing the value of $\mathrm{BCR}=0.98<1$ and $\mathrm{NPV}=-\mathrm{Rp} .1,435,386,864.92<1$ means that the bridge lifting option is not feasible to implement.
\end{abstract}

Keywords. AHP, economic analysis, energy supply, LCC, mechanical problem, oversized vehicles 


\section{Introduction}

PT Adaro Indonesia has a hauling distance of $\pm 90 \mathrm{~km}$ which is located in Tabalong Regency and Balangan Regency, South Kalimantan Province. The hauling road is the lifeblood of the coal transportation route from the mine to the Kelanis port. One of the supporting infrastructure for hauling roads is a hauling bridge whose operation and maintenance is managed by PT Adaro Indonesia.

When Tabalong 1 Bridge (unloaded) \& Tabalong 2 Bridge (loaded) were built, Bina Marga regulations regarding free areas on national roads still required a minimum height of $4 \mathrm{~m}$. Over time, this regulation was updated by requiring the free height of the area above the national road to be at least $5.1 \mathrm{~m}$ in accordance with the Regulation of the Minister of Public Works No. 19/PRT/M/2011 to accommodate oversized vehicles that are being used in Indonesia. This specification has not been met by the national road under the Tabalong Bridge $1 \& 2$ because both bridges were built in the 90 s, so engineering is needed to overcome this.

Several studies related to the selection of alternatives in construction projects. Apriyanto (2008) conducted a study on the comparison of road feasibility using concrete and asphalt structures in a case study of the Demak-Godong Highway. The model taken to make this decision uses the Analytical Hierarchy Process (AHP) method. From the results of the researcher's analysis, it was found that the use of the pavement structure on Jalan Raya Demak - Godong which uses a concrete pavement structure is appropriate, where the criteria are emphasized from technical and non-technical terms, namely: having weather resistance, having resistance to soil movements, have resistance to changes in traffic volume, and maintenance period.

Ginna Vanipa Vanya (2020) conducted research related to the analysis of determining bridge foundations for ease of implementation in the field using the value engineering method in the case study of Sungai Temunih II Bridge, Kusan Hulu District, Tanah Bumbu Regency. The environmental condition where the bridge is planned is a location where the condition of the road that is passed to get to the work location is still a lot of steep incline, hilly and the road surface structure is still a dirt road that has not been paved. Where during the construction period of the project it was not possible to mobilize tools for bridge foundation work to the project site. In determining the bridge foundation to be chosen, there are 3 alternatives, namely: bore pile pile foundation, steel pipe pile foundation and well foundation. Based on the value engineering analysis of the 3 alternative foundations, the recommended foundation is the well foundation.

Currently PT Adaro Indonesia is trying to adjust a vertical clearance under Tabalong Bridge 1 (unloaded) and Tabalong Bridge 2 (loaded). There are 2 alternative designs, namely lowering the elevation of the national road and increasing the elevation of the bridge's upper structure. Efforts to get the height of this free area are very important to ensure the continuity of hauling road operations and ensure that the upper structure of the Tabalong Bridge is not hit by oversized vehicles passing through the national roads. From the two options in this study, an analysis will be carried out to determine the alternative design of the vertical clearance design of the Tabalong Bridge based on non-financial and financial criteria. Non-financial criteria using the AHP (Analytical Hierarchy Process) analysis method and financial criteria using Life Cycle Cost (LCC)/Benefit Cost Ratio (BCR). Then the results of the two alternatives will be compared to obtain appropriate, effective and efficient decision recommendations from the results of the AHP and LCC/BCR analysis.

\section{Research Method}

There are several stages of analysis carried out in data processing in determining the alternative design for the vertical clearance of the Tabalong Bridge. The stages of analysis carried out in this study consisted of:

\subsection{Data Collection}

This study uses a survey method by conducting interviews and distributing questionnaire data as a means of collecting primary data. The number of respondents in this study were 35 people. The results of primary data collection with interviews resulted in two (2) alternative designs and criteria. The two 
alternatives are the option of lowering the elevation of the national road and the option of increasing the elevation of the superstructure of the bridge. From the results of the interview data, non-financial criteria and financial criteria were also generated.

\subsection{AHP analysis}

From the two alternative designs, non-financial criteria analysis was carried out by distributing questionnaire data to produce the best alternative using the AHP (Analytical Hierarchy Process) method. There are five (5) non-financial criteria, namely ease of construction, disruption to hauling operations, risk of construction failure, length of time for construction activities, disturbance to the environment and society. The five non-financial criteria are needed for the decision-making process using the Analytical Hierarchy Process (AHP) method, namely: making a synthesis matrix, normalizing the matrix, weighting values, synthesizing decisions and testing the consistency of questionnaire data.

\subsection{AHP Analysis Results}

The best design alternative was obtained using the AHP (Analytical Hierarchy Process) method based on non-financial criteria.

\subsection{LCC/BCR Analysis}

From the two alternative designs, financial criteria analysis was also carried out by processing secondary data to produce the best alternative using the Life Cycle Cost (LCC)/Benefit Cost Ratio (BCR) method. Where the secondary data consists of consultant RAB, consultant DED, literature studies, previous research, bridge and road layouts. Each of the two alternative designs will be calculated as a whole Life Cycle Cost (LCC) by adding up the investment costs (design \& construction), operational \& maintenance costs, other costs and salvage costs. In addition, each of the two design alternatives will also calculate the Benefit Cost Ratio (BCR) to determine the feasibility of each design alternative.

\subsection{LCC/BCR Analysis Results}

The best design alternative was obtained using the Life Cycle Cost (LCC)/Benefit Cost Ratio (BCR) method based on financial criteria.

\subsection{Comparison and Recommendation Results}

Comparing the results of the analysis of the two alternatives to obtain appropriate, effective and efficient decision recommendations from the results of the AHP and LCC/BCR analysis. The steps in this research are shown in the research flow chart in Figure 1. 


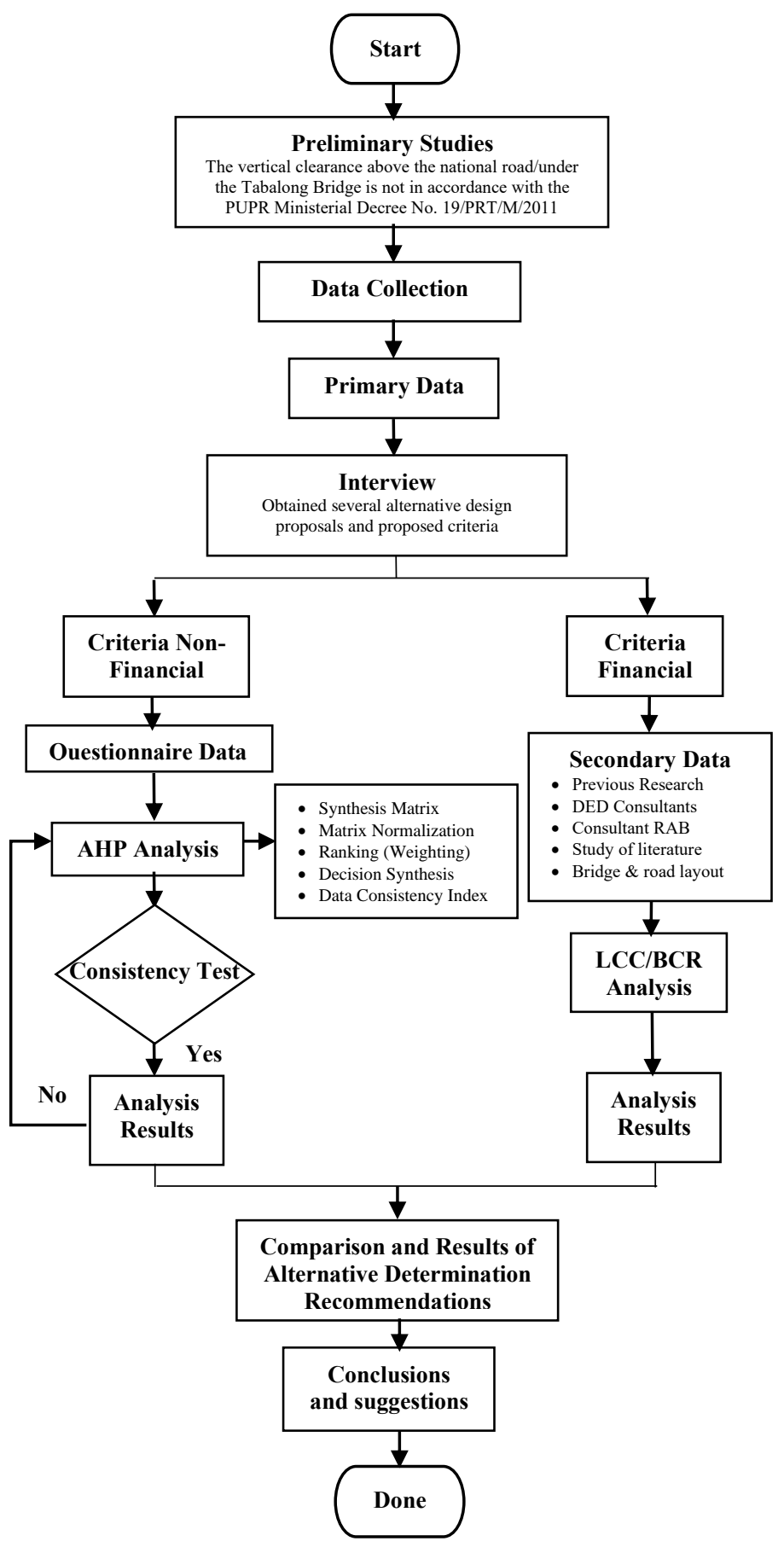

Figure 1. Research Flowchart 


\section{Result and Discussion}

\subsection{Data Collection}

The results of primary data collection by interviewing 35 respondents resulted in two (2) alternative designs and criteria. The two alternatives are the option of lowering the elevation of the national road and the option of increasing the elevation of the superstructure of the bridge. The two alternative designs were analyzed using non-financial criteria by distributing questionnaire data to produce the best alternative using the AHP (Analytical Hierarchy Process) method. Then from the two alternative designs, financial criteria analysis was also carried out by processing secondary data to produce the best alternative using the Life Cycle Cost (LCC)/Benefit Cost Ratio (BCR) method.

\subsection{Analysis Based on Non-Financial Criteria Using AHP Method \\ 3.2.1 Determination of Criteria}

In determining the criteria that will be used in determining alternative designs based on the results of interviews and then distributing questionnaire data where the results of distributing questionnaire data to respondents are used to determine the selection of the best alternative designs and weighting criteria based on non-financial criteria using AHP. The following are some non-financial criteria, namely:

1. Ease of construction

2. Disruption to hauling operations

3. Risk of construction failure

4. Length of time for construction activities

5. Disruption to the environment and society

\subsubsection{Criteria Weighting Analysis}

The weight of the criteria shows the order of priority or influence on the results of the selection of design alternatives to be used. The determination of the priority scale assessment is carried out using a pairwise comparison matrix in qualitative form in the form of numbers indicating the rating scale (19). This priority assessment is based on the assessment of the respondents who have been determined in the process of collecting and processing questionnaire data. From the results of the questionnaire data, the comparison results between pairs of 2 (two) elements of the 5 main criteria can be seen in Table 1.

Table 1. Rating Scale Between 2 (two) Elements

\begin{tabular}{|c|c|c|c|}
\hline Criterion I & Criterion II & $\begin{array}{l}\text { Intensity of } \\
\text { Importance }\end{array}$ & Explanation \\
\hline Ease of construction & $\begin{array}{l}\text { Length of time for } \\
\text { construction activities }\end{array}$ & 3 & $\begin{array}{l}\text { Criterion I is slightly more important } \\
\text { than criterion II }\end{array}$ \\
\hline Ease of construction & $\begin{array}{l}\text { Disruption to the } \\
\text { environment and society }\end{array}$ & 5 & $\begin{array}{l}\text { Criterion I is very important } \\
\text { compared to criterion II }\end{array}$ \\
\hline Disruption to hauling operations & Ease of construction & 3 & $\begin{array}{l}\text { Criterion I is slightly more } \\
\text { important than criterion II }\end{array}$ \\
\hline Disruption to hauling operations & $\begin{array}{l}\text { Length of time for } \\
\text { construction activities }\end{array}$ & 5 & $\begin{array}{l}\text { Criterion I is very important } \\
\text { compared to criterion II }\end{array}$ \\
\hline Disruption to hauling operations & $\begin{array}{l}\text { Disruption to the } \\
\text { environment and society }\end{array}$ & 7 & $\begin{array}{l}\text { Criterion I is clearly more } \\
\text { important than criterion II }\end{array}$ \\
\hline Risk of construction failure & Ease of construction & 5 & $\begin{array}{l}\text { Criterion I is very important } \\
\text { compared to criterion II }\end{array}$ \\
\hline Risk of construction failure & $\begin{array}{l}\text { Disruption to hauling } \\
\text { operations }\end{array}$ & 3 & $\begin{array}{l}\text { Criterion I is slightly more } \\
\text { important than criterion II }\end{array}$ \\
\hline Risk of construction failure & $\begin{array}{l}\text { Length of time for } \\
\text { construction activities }\end{array}$ & 7 & $\begin{array}{l}\text { Criterion I is clearly more } \\
\text { important than criterion II }\end{array}$ \\
\hline Risk of construction failure & $\begin{array}{l}\text { Disruption to the } \\
\text { environment and society }\end{array}$ & 9 & $\begin{array}{l}\text { Criterion I is absolutely more } \\
\text { important than criterion II }\end{array}$ \\
\hline $\begin{array}{l}\text { Length of time for construction } \\
\text { activities }\end{array}$ & $\begin{array}{l}\text { Disruption to the } \\
\text { environment and society }\end{array}$ & 3 & $\begin{array}{l}\text { Criterion I is slightly more } \\
\text { important than criterion II }\end{array}$ \\
\hline
\end{tabular}


Table 2. Assessment Synthesis Matrix for Criteria

\begin{tabular}{|c|c|c|c|c|c|c|}
\hline \multirow[t]{2}{*}{ 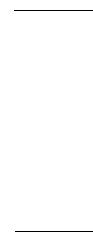 } & \multirow[t]{2}{*}{ Purpose } & \multicolumn{5}{|c|}{ Criteria } \\
\hline & & $\begin{array}{c}\text { Ease of } \\
\text { construction }\end{array}$ & $\begin{array}{l}\text { Disruption } \\
\text { to Hauling } \\
\text { Operations }\end{array}$ & $\begin{array}{c}\text { Risk of } \\
\text { Construction } \\
\text { Failure }\end{array}$ & $\begin{array}{c}\text { Length of } \\
\text { Time for } \\
\text { Construction } \\
\text { Activities }\end{array}$ & $\begin{array}{l}\text { Disruption to } \\
\text { The } \\
\text { Environment } \\
\text { and Society }\end{array}$ \\
\hline \multirow{6}{*}{ 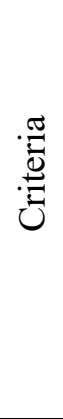 } & Ease of construction & 1 & 0,33 & 0,20 & 3,00 & 5,00 \\
\hline & $\begin{array}{l}\text { Disruption to Hauling } \\
\text { Operations }\end{array}$ & 3,00 & 1 & 0,33 & 5,00 & 7,00 \\
\hline & Risk of Construction Failure & 5,00 & 3,00 & 1 & 7,00 & 9,00 \\
\hline & $\begin{array}{c}\text { Length of Time for } \\
\text { Construction Activities }\end{array}$ & 0,33 & 0,20 & 0,14 & 1 & 3,00 \\
\hline & $\begin{array}{l}\text { Disruption to The } \\
\text { Environment and Society }\end{array}$ & 0,20 & 0,14 & 0,11 & 0,33 & 1 \\
\hline & $\sum$ & 9,53 & 4,68 & 1,79 & 16,33 & 25,00 \\
\hline
\end{tabular}

The value of the rating scale in Table 1 above is processed by making an assessment synthesis matrix for each criterion as shown in Table 2 which forms a matrix of order 5 x 5 adjusting the number of criteria. Then from the assessment synthesis matrix in Table 2, normalization of the criteria matrix is carried out to obtain the weighting value of each criterion as shown in Table 3.

Table 3. Criteria Matrix Normalization

\begin{tabular}{|c|c|c|c|c|c|c|c|c|}
\hline & \multirow[t]{2}{*}{ Purpose } & \multicolumn{5}{|c|}{ Criteria } & \multirow[t]{2}{*}{$\sum$} & \multirow{2}{*}{$\begin{array}{c}\text { Average } \\
\text { Rating } \\
\text { (weight) }\end{array}$} \\
\hline & & $\begin{array}{l}\text { Ease of } \\
\text { constructi } \\
\text { on }\end{array}$ & $\begin{array}{l}\text { Disruption } \\
\text { to Hauling } \\
\text { Operations }\end{array}$ & $\begin{array}{c}\text { Risk of } \\
\text { Construction } \\
\text { Failure }\end{array}$ & $\begin{array}{l}\text { Length of } \\
\text { Time for } \\
\text { Construction } \\
\text { Activities }\end{array}$ & $\begin{array}{l}\text { Disruption to } \\
\text { The } \\
\text { Environment } \\
\text { and Society }\end{array}$ & & \\
\hline \multirow{5}{*}{ 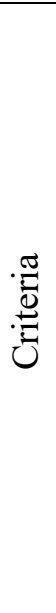 } & $\begin{array}{c}\text { Ease of } \\
\text { construction }\end{array}$ & 0,10 & 0,07 & 0,11 & 0,18 & 0,20 & 0,67 & $13,44 \%$ \\
\hline & $\begin{array}{l}\text { Disruption to } \\
\text { Hauling }\end{array}$ & 0,31 & 0,21 & 0,19 & 0,31 & 0,28 & 1,30 & $26,02 \%$ \\
\hline & $\begin{array}{l}\text { Operations } \\
\text { Risk of } \\
\text { Construction } \\
\text { Failure }\end{array}$ & 0,52 & 0,64 & 0,56 & 0,43 & 0,36 & 2,51 & $50,28 \%$ \\
\hline & $\begin{array}{l}\text { Length of Time } \\
\text { for Construction } \\
\text { Activities }\end{array}$ & 0,03 & 0,04 & 0,08 & 0,06 & 0,12 & 0,34 & $6,78 \%$ \\
\hline & $\begin{array}{l}\text { Disruption to The } \\
\text { Environment and } \\
\text { Society }\end{array}$ & 0,02 & 0,03 & 0,06 & 0,02 & 0,04 & 0,17 & $3,48 \%$ \\
\hline
\end{tabular}

The weighting value of each criterion is sorted by the highest weight value to the lowest weight value to show the most priority criteria as can be seen in Table 4 . 
Table 4. Criteria Intensity Ranking

\begin{tabular}{lcc}
\hline \multicolumn{1}{c}{ Criteria } & Weight & Important Intensity Ranking \\
\hline Risk of Construction Failure & $50,28 \%$ & I \\
Disruption to Hauling Operations & $26,02 \%$ & II \\
Ease of construction & $13,44 \%$ & III \\
Length of Time for Construction Activities & $6,78 \%$ & IV \\
Disruption to The Environment and Society & $3,48 \%$ & V \\
\hline
\end{tabular}

From Table 4 it can be explained as follows:

1. The risk of construction failure is the first priority, because it will have an impact on the cessation of coal production and K3 (Occupational Health and Safety) issues. Especially for work at a height that has a fairly high risk of danger.

2. Disruption to hauling operations becomes the second priority after the risk of construction failure, because there will be a slowdown in the speed of the coal transporting unit on the bridge as a result of opening and closing traffic on the Tabalong Bridge.

3. Ease of construction becomes the third priority after the length of time construction activities and disturbances to the environment \& society. Ease of construction, length of time for construction activities and disturbance to the environment \& society are aspects of the criteria that are interrelated in the selection of alternative designs for the vertical clearance of the Tabalong Bridge.

In the next stage of the two alternatives, namely the option of lowering the elevation of the national $\operatorname{road}($ Alt $\mathrm{A}$ ) and the option of increasing the elevation of the bridge's upper structure (Alt B), an alternative matrix and normalization of the alternative matrix will be carried out based on predetermined criteria including:

1. Criteria for Ease of Construction

a. Alternative Matrix

It can be seen in Table 5 that the results of the questionnaire data for aspects of the criteria for ease of construction. A comparison of the 2 alternatives using a $2 \times 2$ order matrix where a rating scale of 5 was obtained from the questionnaire data. Then the total value scale for each alternative column will be 1.20 and 6.00 , respectively.

Table 5. Alternative Matrix

\begin{tabular}{|c|c|c|c|}
\hline & \multirow[t]{2}{*}{ Purpose } & \multicolumn{2}{|c|}{ Alternative } \\
\hline & & $\mathrm{A}$ & B \\
\hline \multirow{3}{*}{ 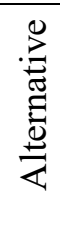 } & $\mathrm{A}$ & 1 & 5,00 \\
\hline & B & 0,20 & 1 \\
\hline & $\sum$ & 1,20 & 6,00 \\
\hline
\end{tabular}

b. Matrix Normalization

In Table 6 , the alternative matrix normalization is carried out to obtain the weighting value of each alternative. In this case, the weight value of the alternative for lowering national roads is $83.33 \%$ greater than the alternative for lifting bridges. 
Table 6. Alternative Matrix Normalization

\begin{tabular}{|c|c|c|c|c|c|}
\hline & \multirow[t]{2}{*}{ Purpose } & \multicolumn{2}{|c|}{ Alternative } & \multirow[t]{2}{*}{$\sum$} & \multirow{2}{*}{$\begin{array}{c}\text { Average } \\
\text { Rating } \\
\text { (weight) }\end{array}$} \\
\hline & & A & B & & \\
\hline 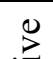 & $\mathrm{A}$ & 0,83 & 0,83 & 1,67 & $83,33 \%$ \\
\hline$\frac{\bar{Q}}{\stackrel{ \pm}{Z}}$ & B & 0,17 & 0,17 & 0,33 & $16,67 \%$ \\
\hline
\end{tabular}

2. Criteria for Disruption to Hauling Operations

a. Alternative Matrix

It can be seen in Table 7 that the results of the questionnaire data for aspects of the criteria for disruption to hauling operations. A comparison of the 2 alternatives using a $2 \times 2$ order matrix where a rating scale of 7 was obtained from the questionnaire data. Then the total value scale for each alternative column will be 1.14 and 8.00 , respectively.

Table 7. Alternative Matrix

\begin{tabular}{|c|c|c|c|}
\hline & \multirow[t]{2}{*}{ Purpose } & \multicolumn{2}{|c|}{ Alternative } \\
\hline & & A & B \\
\hline \multirow{3}{*}{ 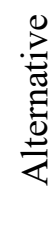 } & A & 1 & 7,00 \\
\hline & B & 0,14 & 1 \\
\hline & $\sum$ & 1,14 & 8,00 \\
\hline
\end{tabular}

b. Matrix Normalization

In Table 8, the alternative matrix normalization is carried out to obtain the weighting value of each alternative. In this case, the weight value of the alternative for lowering national roads is $87.50 \%$ greater than the alternative for lifting bridges.

Table 8. Alternative Matrix Normalization

\begin{tabular}{|c|c|c|c|c|c|}
\hline & \multirow[t]{2}{*}{ Purpose } & \multicolumn{2}{|c|}{ Alternative } & \multirow[t]{2}{*}{$\sum$} & \multirow{2}{*}{$\begin{array}{c}\text { Average } \\
\text { Rating } \\
\text { (weight) }\end{array}$} \\
\hline & & A & B & & \\
\hline$\stackrel{0}{\Xi}$ & A & 0,88 & 0,88 & 1,75 & $87,50 \%$ \\
\hline 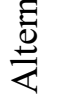 & B & 0,13 & 0,13 & 0,25 & $12,50 \%$ \\
\hline
\end{tabular}

3. Criteria for Risk of Construction Failure

a. Alternative Matrix

It can be seen in Table 9 that the results of the questionnaire data for aspects of the criteria for risk of construction failure. A comparison of the 2 alternatives using a $2 \times 2$ order matrix where a rating scale of 9 was obtained from the questionnaire data. Then the total value scale for each alternative column will be 1.11 and 10.00 , respectively. 
Table 9. Alternative Matrix

\begin{tabular}{|c|c|c|c|}
\hline & \multirow[t]{2}{*}{ Purpose } & \multicolumn{2}{|c|}{ Alternative } \\
\hline & & $\mathrm{A}$ & B \\
\hline \multirow{3}{*}{ 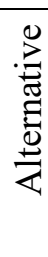 } & A & 1 & 9,00 \\
\hline & B & 0,11 & 1 \\
\hline & $\sum$ & 1,11 & 10,00 \\
\hline
\end{tabular}

b. Matrix Normalization

In Table 10, the alternative matrix normalization is carried out to obtain the weighting value of each alternative. In this case, the weight value of the alternative for lowering national roads is $90.00 \%$ greater than the alternative for lifting bridges.

Table 10. Alternative Matrix Normalization

\begin{tabular}{|c|c|c|c|c|c|}
\hline & \multirow{2}{*}{ Purpose } & \multicolumn{2}{|c|}{ Alternative } & \multirow[t]{2}{*}{$\sum$} & \multirow{2}{*}{$\begin{array}{c}\text { Average } \\
\text { Rating } \\
\text { (weight) }\end{array}$} \\
\hline & & A & B & & \\
\hline$\$$ & $\mathrm{~A}$ & 0,90 & 0,90 & 1,80 & $90,00 \%$ \\
\hline 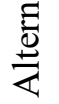 & B & 0,10 & 0,10 & 0,20 & $10,00 \%$ \\
\hline
\end{tabular}

4. Criteria for Length of Time for Construction Activities

a. Alternative Matrix

It can be seen in Table 11 that the results of the questionnaire data for aspects of the criteria for length of time for construction activities. A comparison of the 2 alternatives using a $2 \times 2$ order matrix where a rating scale of 3 was obtained from the questionnaire data. Then the total value scale for each alternative column will be 1.33 and 4.00 , respectively.

Table 11. Alternative Matrix

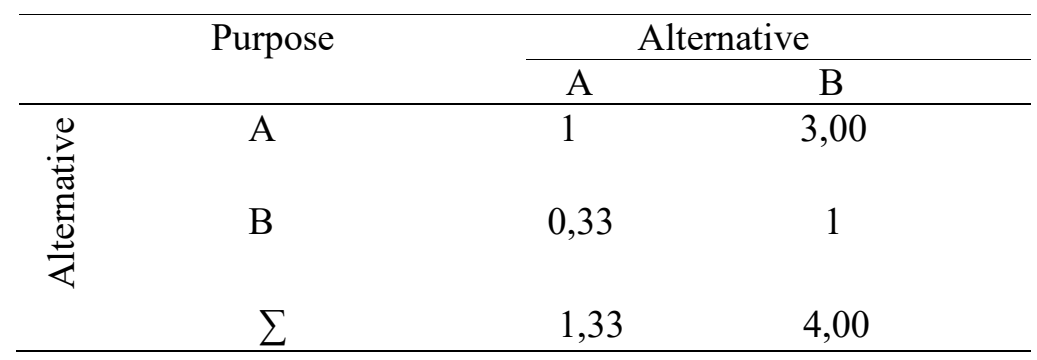

b. Matrix Normalization

In Table 12, the alternative matrix normalization is carried out to obtain the weighting value of each alternative. In this case, the weight value of the alternative for lowering national roads is $75.00 \%$ greater than the alternative for lifting bridges. 
Table 12. Alternative Matrix Normalization

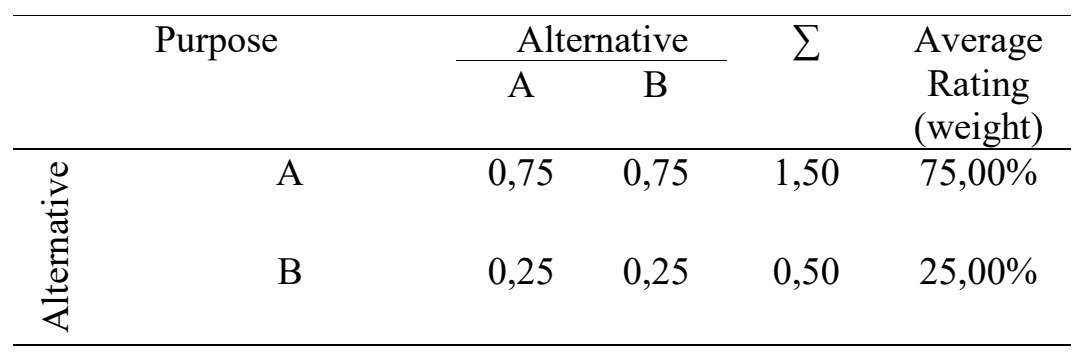

5. Criteria for Disruption to The Environment and Society

a. Alternative Matrix

It can be seen in Table 13 that the results of the questionnaire data for aspects of the criteria for disruption to the environment and society. A comparison of the 2 alternatives using a $2 \times 2$ order matrix where a rating scale of 3 was obtained from the questionnaire data. Then the total value scale for each alternative column will be 4.00 and 1.33 , respectively.

Table 13. Alternative Matrix

\begin{tabular}{|c|c|c|c|}
\hline & \multirow[t]{2}{*}{ Purpose } & \multicolumn{2}{|c|}{ Alternative } \\
\hline & & A & B \\
\hline \multirow{3}{*}{ 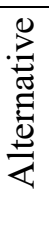 } & A & 1 & 0,33 \\
\hline & B & 3,00 & 1 \\
\hline & $\sum$ & 4,00 & 1,33 \\
\hline
\end{tabular}

b. Matrix Normalization

In Table 14, the alternative matrix normalization is carried out to obtain the weighting value of each alternative. In this case, the weight value of the alternative for lifting bridge is $75.00 \%$ greater than the alternative for lowering national roads.

Table 14. Alternative Matrix Normalization

\begin{tabular}{|c|c|c|c|c|c|}
\hline & \multirow[t]{2}{*}{ Purpose } & \multicolumn{2}{|c|}{ Alternative } & \multirow[t]{2}{*}{$\sum$} & \multirow{2}{*}{$\begin{array}{c}\text { Average } \\
\text { Rating } \\
\text { (weight) }\end{array}$} \\
\hline & & A & B & & \\
\hline$\stackrel{8}{>}$ & A & 0,25 & 0,25 & 0,50 & $25,00 \%$ \\
\hline$\frac{\bar{D}}{\mathbb{E}}$ & B & 0,75 & 0,75 & 1,50 & $75,00 \%$ \\
\hline
\end{tabular}

\subsubsection{Decision Synthesis}

From the result matrix data and the normalization of the criteria and alternative matrices that have been carried out in the explanation of the previous table, the resulting matrix of decision synthesis on the selection of design alternatives can be seen in Table 15 . 
Table 15. Decision Synthesis

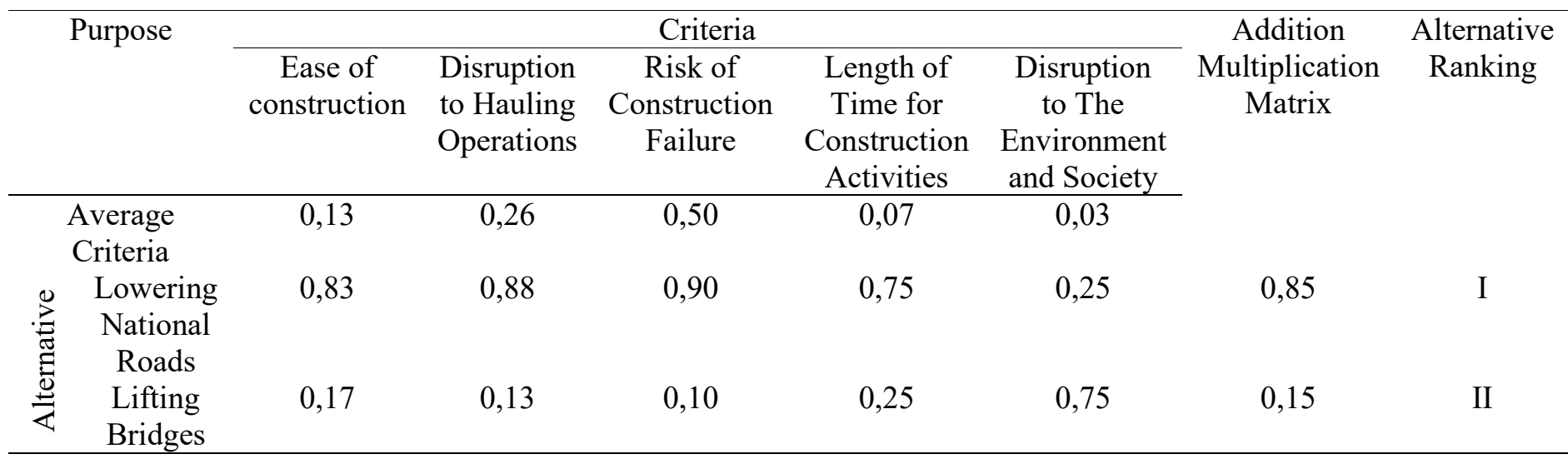

The following is an explanation of the calculations to form a decision synthesis matrix in Table 15.

1. Look for the sum of the multiplication matrices in lowering national road line with the formula.

$=(0,83 \times 0,13)+(0,88 \times 0,26)+(0,9 \times 0,5)+(0,75 \times 0,07)+(0,25 \times 0,03)$

$=0,85$

2. Look for the sum of the multiplication matrices in lifting bridge line with the formula.

$=(0,17 \times 0,13)+(0,13 \times 0,26)+(0,1 \times 0,5)+(0,25 \times 0,07)+(0,75 \times 0,03)$

$=0,15$

\subsubsection{Data Consistency Index}

To calculate the Data Consistency Index, the value obtained from the average rating (weight) must be normalized to obtain the eigenvectors by adding up the weights of each column in the alternative matrix which has previously been multiplied by the average rating (weight) on each criterion. be the sum of the entries in each criterion. The results of these calculations are in Table 16.

1. Find the value of the addition of the multiplication matrix in the row of criteria for ease of construction with a formula.

$$
\begin{aligned}
& =(1,00 \times 0,13)+(0,33 \times 0,26)+(0,20 \times 0,50)+(3,00 \times 0,07)+(5,00 \times 0,03) \\
& =0,70
\end{aligned}
$$

2. Find the value of the addition of the multiplication matrix in the row of criteria for disruption to hauling operations with a formula.

$=(3,00 \times 0,13)+(1,00 \times 0,26)+(0,33 \times 0,50)+(5,00 \times 0,07)+(7,00 \times 0,03)$

$=1,41$

3. Find the value of the addition of the multiplication matrix in the row of criteria for risk of construction failure with a formula.

$=(5,00 \times 0,13)+(3,00 \times 0,26)+(1,00 \times 0,50)+(7,00 \times 0,07)+(9,00 \times 0,03)$

$=2,74$

4. Find the value of the addition of the multiplication matrix in the row of criteria for length of time for construction activities with a formula.

$=(0,33 \times 0,13)+(0,20 \times 0,26)+(0,14 \times 0,50)+(1,00 \times 0,07)+(3,00 \times 0,03)$

$=0,34$

5. Find the value of the addition of the multiplication matrix in the row of criteria for disruption to the environment and society with a formula.

$=(0,20 \times 0,13)+(0,14 \times 0,26)+(0,11 \times 0,50)+(0,33 \times 0,07)+(1,00 \times 0,03)$

$=0,18$ 
Table 16. Sum of Criteria Matrix Entries

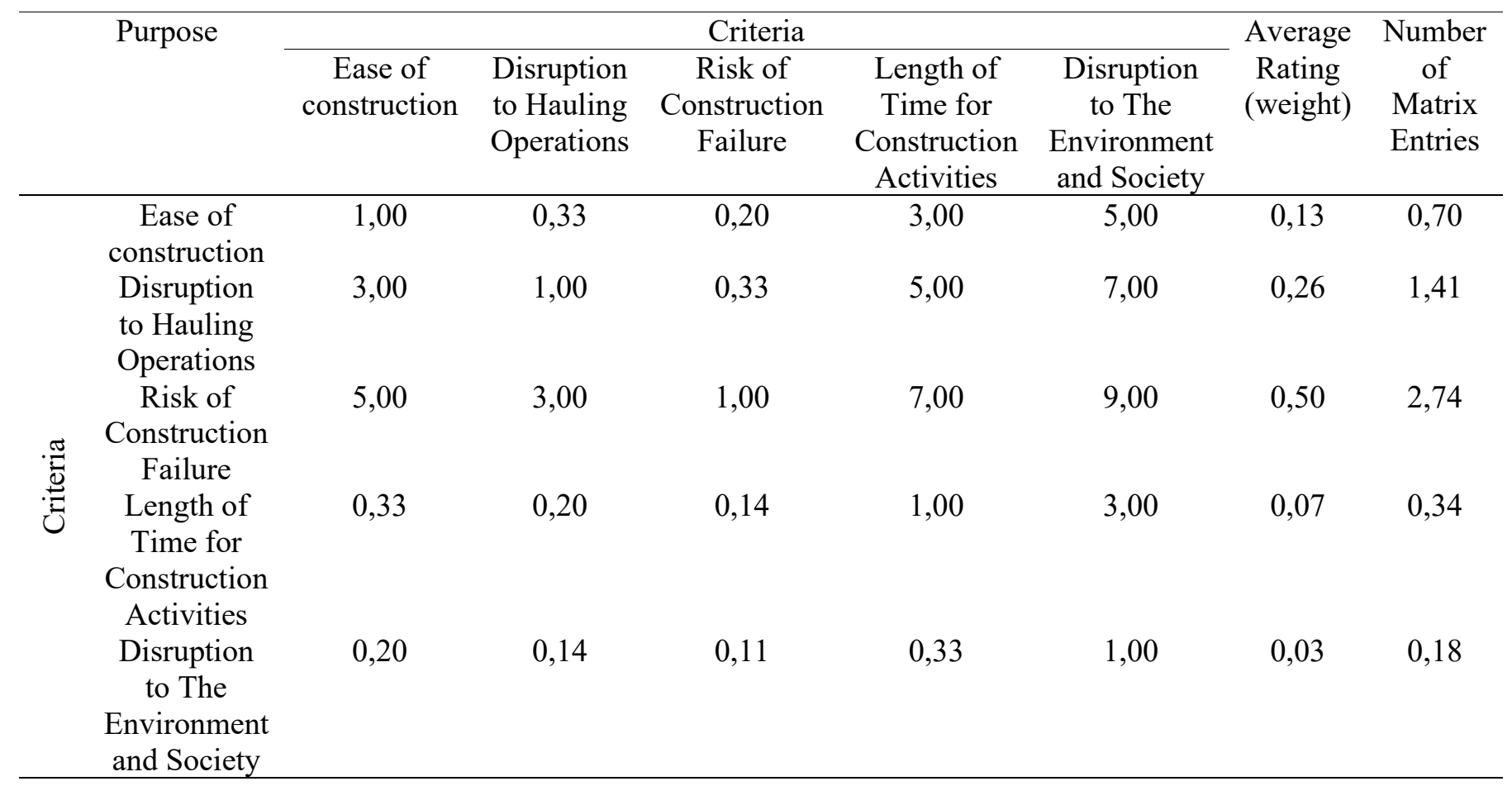

From the results of Table 16, then the consistency ratio is determined from the data, the consistency index value is obtained from the results of the maximum eigenvalue minus the order matrix divided by the order matrix minus 1. Before getting the consistency index, it is necessary to find the maximum eigenvalue as shown in Table 17 by adding up all the multiplication of the criteria values with their eigenvectors. From the results of Table 17, the maximum eigen value is 5.24. This consistency index must be compared with a random index whose value has been determined by Saaty. For the order of the matrix 5 (according to the number of criteria) the random index is 1.11 .

Table 17. Maximum Eigen Value

\begin{tabular}{cccc}
\hline Purpose & $\begin{array}{c}\text { Number of Matrix } \\
\text { Entries }\end{array}$ & $\begin{array}{c}\text { Average Rating } \\
\text { (weight) }\end{array}$ & Eigen Value (e) \\
\hline Ease of construction & 0,70 & 0,13 & 5,20 \\
Disruption to Hauling & 1,41 & 0,26 & 5,43 \\
Operations & & 0,50 & 5,46 \\
. & 2,74 & 0,07 & 5,03 \\
\hline $\begin{array}{c}\text { Risk of Construction Failure } \\
\text { Length of Time for }\end{array}$ & 0,34 & 0,03 & 5,09 \\
$\begin{array}{c}\text { Construction Activities } \\
\text { Disruption to The Environment } \\
\text { and Society }\end{array}$ & 0,18 & Average $\left(\mathrm{e}_{\max }\right)$ & 5,24 \\
\hline
\end{tabular}

Furthermore, the results of the acquisition of the average eigen values (emax) will be used as a calculation element to determine the consistency ratio.
Consistency Index (CI) $\quad=(($ emaks-n) $) /((\mathrm{n}-1))$
Consistency Index $(\mathrm{CI}) \quad=((5,24-5)) /((5-1))$
Consistency Index (CI) $\quad=0,06$
Random Index (RI) $\quad=1,11$ 
Then the results of the consistency ratio based on the consistency index and random index values above are as follows:

Consistency Ratio $(\mathrm{CR}) \quad=\mathrm{CI} / \mathrm{RI}$

Consistency Ratio (CR) $\quad=0,06 / 1,11$

Consistency Ratio (CR) $\quad=0,05<0,1(\mathrm{OK})$

From the results above, it was found that the consistency ratio was below $0.1(10 \%)$, so in accordance with the standards set by Saaty, the results of distributing questionnaire data from the respondents were consistent, so the AHP calculation did not need to be repeated.

\subsection{Analysis Based on Financial Criteria Using Life Cycle Cost (LCC)/Benefit Cost Ratio (BCR) Method}

In this study, two (2) alternative designs were obtained from the interviews. Then from the two alternative designs, financial criteria analysis was carried out by processing secondary data to produce the best alternative using the Life Cycle Cost (LCC) / Benefit Cost Ratio (BCR) method. Table 18 shows the data for LCC builders, namely: initial cost, operational \& maintenance costs, additional costs and salvage value. Investment costs (initial costs) consist of planning/design costs and construction costs.

Table 18. LCC Comparative Analysis of Lowering National Road and Lifting Bridge

\begin{tabular}{|c|c|c|c|}
\hline No & Description & Lowering National Road & Lifting Bridge \\
\hline \multirow[t]{3}{*}{1} & Initial Cost & 25.208.329.668,53 & 48.619.636.851,77 \\
\hline & 0th year Planning Cost & $203.365 .768,53$ & $392.234 .231,47$ \\
\hline & 0th year Construction Cost & $25.004 .963 .900,00$ & $48.227 .402 .620,30$ \\
\hline \multirow[t]{3}{*}{2} & $\begin{array}{l}\text { Operational \& Maintenance } \\
\text { Costs }\end{array}$ & 3.806.894.393,28 & $5.350 .117 .079,31$ \\
\hline & 0 th year $\mathrm{O} / \mathrm{M}$ Cost & $218.760 .000,00$ & $307.440 .000,00$ \\
\hline & Year 1 to year $20 \mathrm{O} / \mathrm{M}$ Cost & $3.588 .134 .393,28$ & $5.042 .677 .079,31$ \\
\hline \multirow[t]{4}{*}{3} & Additional Costs & 3.639.378.200,00 & 23.562.500.000,00 \\
\hline & 0th year Land acquisition costs & $3.639 .378 .200,00$ & Nothing \\
\hline & $\begin{array}{l}\text { 0th year Cost of lost } \\
\text { production profit }\end{array}$ & Nothing & 23.562.500.000,00 \\
\hline & Risk Cost & Low & High \\
\hline \multirow[t]{3}{*}{4} & Salvage Cost & Nothing & Nothing \\
\hline & LCC atau NPV Cost (Rp) & 32.654.602.261,81 & 77.532.253.931,08 \\
\hline & Deviation (Rp) & & 44.877.651.669,27 \\
\hline
\end{tabular}

For a comparative analysis of the LCC with the option of lowering the elevation of the national road and increasing the elevation of the bridge's upper structure, it can be seen in Table 18 where the option of lowering the elevation of the national road is Rp. 44,877,651,669.27 more efficient than the option to increase the elevation of the bridge's upper structure.

Based on Figure 2 shows an illustration in the form of a graph of the difference between the cost of the LCC option for lowering national road of Rp. 32,654,602,261.81 and the cost of the LCC bridge lifting option is Rp. 77,532,253,931.08 obtained from the results of previous calculations. Where in the LCC cost graph also shows several components of the cost of compiling the LCC which consists of initial cost, operational \& maintenance costs, additional costs and salvage value. 


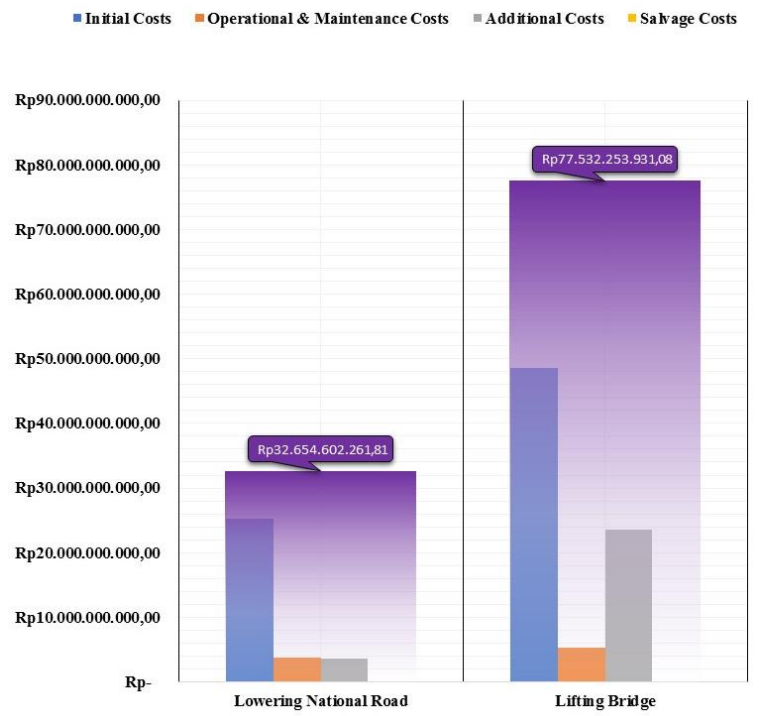

Figure 2. Graph of LCC Comparative Analysis of Lowering National Road and Lifting Bridge

Another term for the LCC value is the NPV Cost value which is part of the calculation of the Benefit Cost Ratio (BCR) analysis of the two alternatives which can be seen in Table 20 and Table 21. The following is an example of an explanation of the calculation to form a Cash Flow Benefit Cost Ratio (BCR) with lowering national road, it can be seen in Table 19. The calculation assumes an increase in operating and maintenance costs (O/M Cost) every year by $3 \%$ (inflation), a useful life of 20 years and an interest rate of $10 \%$.

1. Find $\mathrm{P} / \mathrm{F}, \mathrm{i}, \mathrm{n}$ with the formula.

$\mathrm{P} / \mathrm{F}, \mathrm{i}, \mathrm{n}=[1 /(1+\mathrm{i})]^{\wedge} \mathrm{N}$

$\mathrm{P} / \mathrm{F}, 10 \%, 0=[1 /(1+0,1)]^{\wedge} 0=1$

$\mathrm{P} / \mathrm{F}, 10 \%, 1=[1 /(1+0,1)]^{\wedge} 1=0,91$

$\mathrm{P} / \mathrm{F}, 10 \%, 2=[1 /(1+0,1)]^{\wedge} 2=0,83$

The calculation of $\mathrm{P} / \mathrm{F}, \mathrm{i}, \mathrm{n}$ is carried out in the same way, until the 20th year.

2. Find the cost of operation and maintenance $(\mathrm{O} / \mathrm{M}$ Cost $)$ every year by considering a cost increase of $3 \%$ (inflation) with the formula.

$\mathrm{F}=\mathrm{P}[(1+\mathrm{i})]^{\wedge} \mathrm{N}$

0th year O/M Cost $\quad=218.760 .000,00 \times[(1+0,03)]^{\wedge} 0=218.760 .000,00$

1 st year $\mathrm{O} / \mathrm{M}$ Cost $\quad=218.760 .000,00 \times[(1+0,03)]^{\wedge} 1=225.322 .800,00$

2nd year O/M Cost $=218.760 .000,00 \times[(1+0,03)]^{\wedge} 2=232.082 .484,00$

The calculation of $\mathrm{O} / \mathrm{M}$ costs is carried out in the same way, until the 20th year.

3. Find the cost each year with the formula.

Cost $=$ Initial Cost $+\mathrm{O} / \mathrm{M}$ Cost + Overhaul Cost + Land Acquisition Cost

0 th year Cost $=25.208 .329 .668,53+218.760 .000,00+0+3.639 .378 .200,00$

$$
=29.066 .467 .868,53
$$

1st year Cost $=0+225.322 .800,00+0+0=225.322 .800,00$

2nd year Cost $=0+232.082 .484,00+0+0=232.082 .484,00$

3 rd year Cost $=0+239.044 .958,52+0+0=239.044 .958,52$

4th year Cost $=0+246.216 .307,28+0+0=246.216 .307,28$

5th year Cost $=0+253.602 .796,49+760.808 .389,48+0=1.014 .411 .185,98$

The cost calculation is carried out in the same way every year, until the 20th year and for overhaul costs every 5 years it is assumed that the maintenance costs are $3 \mathrm{x}$ in the 5 th, $-10,-15$ and -20 
years.

5 th year Overhaul Cost $=3 \times 5$ th year O/M Cost $=3 \times 253.602 .796,49=760.808 .389,48$

4. Find the NPV Cost every year with the formula.

$$
\begin{aligned}
& \text { NPV Cost = Cost } \mathrm{x}(\mathrm{P} / \mathrm{F}, \mathrm{i}, \mathrm{n}) \\
& \begin{aligned}
\text { 0th year NPV Cost } & =0 \text { th year Cost } \mathrm{x}(\mathrm{P} / \mathrm{F}, 10 \%, 0)=29.066 .467 .868,53 \times 1 \\
& =29.066 .467 .868,53 \\
1 \text { st year NPV Cost } & =1 \text { st year Cost } \mathrm{x}(\mathrm{P} / \mathrm{F}, 10 \%, 1)=225.322 .800,00 \times 0,91 \\
& =204.838 .909,09 \\
2 \text { nd year NPV Cost } & =2 \text { nd year Cost } \mathrm{x}(\mathrm{P} / \mathrm{F}, 10 \%, 2)=232.082 .484,00 \times 0,83 \\
& =191.803 .705,79
\end{aligned}
\end{aligned}
$$

5. Find Total NPV Cost from year 0 to year 20 using the formula

$$
\begin{aligned}
\Sigma \text { NPV Cost } & =0 \text { th year NPV Cost }+1 \text { st year NPV Cost } \ldots+20 \text { th year NPV Cost } \\
& =29.066 .467 .868,53+204.838 .909,09 \ldots+234.919 .299,40 \\
& =32.654 .602 .261,81
\end{aligned}
$$

The calculation of NPV cost every year is carried out in the same way, until the 20th year.

6. Looking for benefits from year 1 to year 20 by considering an increase in costs of $3 \%$ (inflation) with the formula. $\mathrm{P}$ value refers to Table 19.

$\mathrm{F}=\mathrm{P}[(1+\mathrm{i})]^{\wedge} \mathrm{N}$

Oth year Benefit $\quad=0$

\begin{tabular}{|c|c|c|c|c|c|}
\hline Description & Unit & Volume & Unit Price & Total & Remark \\
\hline $\begin{array}{l}\text { Consultant service } \\
\text { incident assessment }\end{array}$ & Ls & 1 & 150.151 .346 & $150.151 .346,18$ & \\
\hline $\begin{array}{l}\text { Bridge structure repair } \\
\text { (reinforcement) }\end{array}$ & Ls & 1 & 122.835 .149 & $122.835 .148,80$ & \\
\hline Bridge portal repair & Ls & 1 & $\begin{array}{r}30.416 .323 \\
\text { Sub Total }= \\
\text { Total }=\end{array}$ & $\begin{array}{c}30.416 .322,56 \\
303.402 .817,54 \\
7.281 .667 .620,86\end{array}$ & $\begin{array}{l}\text { for } 1 \mathrm{x} \text { Incident } \\
\text { If it is assumed to } \\
\text { occur } 24 \mathrm{x} \\
\text { Incidents/year }\end{array}$ \\
\hline
\end{tabular}

1st year Benefit $\quad=7.281 .667 .620,86 \times[(1+0,03)]^{\wedge} 0=7.281 .667 .620,86$

2 nd year Benefit $\quad=7.281 .667 .620,86 \times[(1+0,03)]^{\wedge} 1=7.500 .117 .649,49$

3rd year Benefit $\quad=7.281 .667 .620,86 \times[(1+0,03)]^{\wedge} 2=7.725 .121 .178,97$

The benefit calculation is carried out in the same way every year, until the 20th year. Year 1 benefits of Rp. 7,281,667,620.86 is assumed to be equal to the cost of handling bridge damage due to being hit if the bridge clearance height adjustment project is not implemented. If the project is implemented, there will be no more costs for bridge damage so it is considered a benefit.

Table 19. Components of Bridge Damage Due to Hit by High Vehicle Units Community

7. Find the NPV Benefit every year with the formula.

NPV Benefit $=$ Benefit $x(\mathrm{P} / \mathrm{F}, \mathrm{i}, \mathrm{n})$

0 th year NPV Benefit $=0$ th year Benefit $\times(\mathrm{P} / \mathrm{F}, 10 \%, 0)=0 \times 1=0$

1 st year NPV Benefit $=1$ st year Benefit $\times(P / F, 10 \%, 1)=7.281 .667 .620,86 \times 0,91$ $=6.619 .697 .837,15$

2nd year NPV Benefit $=2$ nd year Benefit $\mathrm{x}(\mathrm{P} / \mathrm{F}, 10 \%, 2)=7.500 .117 .649,49 \times 0,83$ $=6.198 .444 .338,42$

The calculation of NPV benefit every year is carried out in the same way, until the 20th year. 
8. Find Total NPV Benefit from year 0 to year 20 with the formula.

$\Sigma$ NPV Benefit $\quad=0$ th year NPV Benefit +1 st year NPV Benefit... +20 th year NPV Benefit

$=0+6.619 .697 .837,15 \ldots+1.897 .948 .472,07$

$=76.096 .867 .066,15$

9. Find Total NPV (Benefit - Cost) from year 0 to year 20 with the formula.

Total NPV (Benefit - Cost) $=\Sigma$ NPV Benefit $-\Sigma$ NPV Cost

$=76.096 .867 .066,15-32.654 .602 .261,81$

$=43.442 .264 .804,34$

10. Find the Benefit Cost Ratio (BCR) with the formula.

$\mathrm{BCR}=(\Sigma$ NPV Benefits $) /(\Sigma$ NPV Cost $)$

$=76.096 .867 .066,15 / 32.654 .602 .261,81$

$=2,33$

11. Find the Internal Rate of Return (IRR) with the formula.

$\mathrm{IRR}=\mathrm{i} 1+\mathrm{i} 2+\mathrm{NPV} 1 /(\mathrm{NPV} 1-\mathrm{NPV} 2)$

If using the excel formula type $=$ IRR (block on the results of $\mathrm{Bi}-\mathrm{Ci}$ starting from the beginning of the year to year -20) then ENTER so that the IRR value is $15.09 \%$.

The results of the Benefit Cost Ratio (BCR) analysis obtained the option for lowering the elevation of national roads with a BCR value of $2.33>1$ and NPV (benefit/cost) = Rp. $43,442,264,804.34>1$ means that the option or lowering the elevation of national roads is feasible. While the option for increasing the elevation of the bridge's upper structure results in the analysis with the value of $\mathrm{BCR}=0.98<1$ and NPV (benefit/cost) $=-\mathrm{Rp} .1,435,386,864.92<1$ means that the option for increasing the elevation of the bridge's upper structure is not feasible. The calculation assumes an increase in operating and maintenance costs ( $\mathrm{O} / \mathrm{M}$ Cost) every year by $3 \%$ (inflation), a useful life of 20 years and an interest rate of $10 \%$. 
Table 20. Cash Flow BCR With Option for Lowering National Road

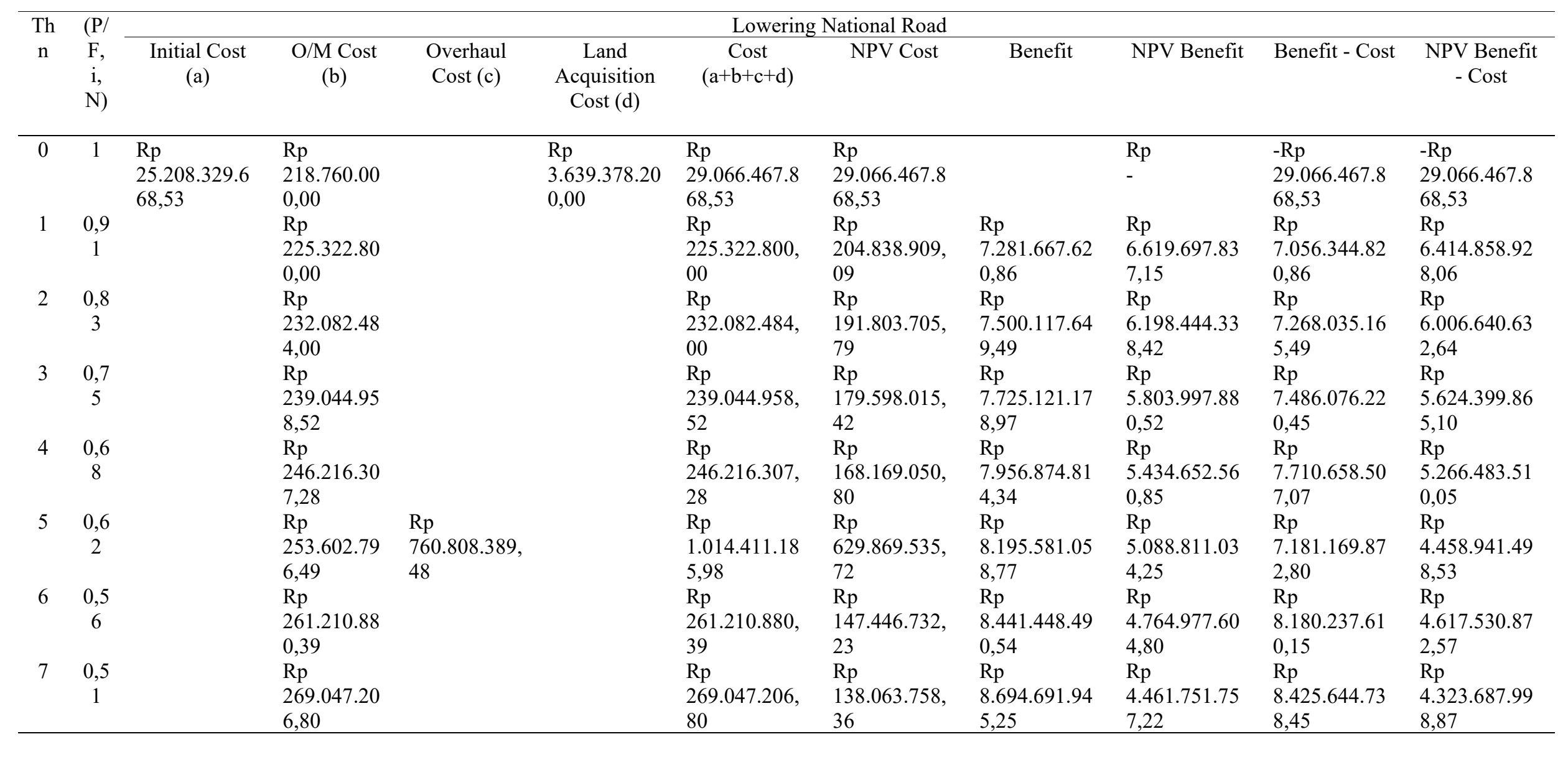


Table 20. Continue

\begin{tabular}{|c|c|c|c|c|c|c|c|c|c|c|c|}
\hline $\begin{array}{l}\text { Th } \\
\mathrm{n}\end{array}$ & $\begin{array}{c}(\mathrm{P} / \\
\mathrm{F}, \\
\mathrm{i}, \\
\mathrm{N}) \\
\end{array}$ & \multicolumn{10}{|c|}{ Lowering National Road } \\
\hline 8 & 0,4 & & $\mathrm{Rp}$ & & & $\mathrm{Rp}$ & $\mathrm{Rp}$ & $\mathrm{Rp}$ & $\mathrm{Rp}$ & $\mathrm{Rp}$ & $\mathrm{Rp}$ \\
\hline 9 & 0,4 & & $\mathrm{Rp}$ & & & $\mathrm{Rp}$ & $\mathrm{Rp}$ & $\mathrm{Rp}$ & $\mathrm{Rp}$ & $\mathrm{Rp}$ & $\mathrm{Rp}$ \\
\hline & 2 & & $\begin{array}{l}285.432 .18 \\
1,69\end{array}$ & & & $\begin{array}{l}285.432 .181, \\
69\end{array}$ & $\begin{array}{l}121.051 .108, \\
46\end{array}$ & $\begin{array}{l}9.224 .198 .68 \\
4,72\end{array}$ & $\begin{array}{l}3.911 .960 .69 \\
3,58\end{array}$ & $\begin{array}{l}8.938 .766 .50 \\
3,02\end{array}$ & $\begin{array}{l}3.790 .909 .58 \\
5,12\end{array}$ \\
\hline 11 & 0,3 & & $\mathrm{Rp}$ & & & $\mathrm{Rp}$ & $\mathrm{Rp}$ & $\mathrm{Rp}$ & $\mathrm{Rp}$ & $\mathrm{Rp}$ & $\mathrm{Rp}$ \\
\hline & 5 & & $\begin{array}{l}302.815 .00 \\
1,56\end{array}$ & & & $\begin{array}{l}302.815 .001 \text {, } \\
56\end{array}$ & $\begin{array}{l}106.134 .810 \text {, } \\
72\end{array}$ & $\begin{array}{l}9.785 .952 .38 \\
4,62\end{array}$ & $\begin{array}{l}3.429 .916 .61 \\
1,42\end{array}$ & $\begin{array}{l}9.483 .137 .38 \\
3,06\end{array}$ & $\begin{array}{l}3.323 .781 .80 \\
0,71\end{array}$ \\
\hline 12 & 0,3 & & $\mathrm{Rp}$ & & & $\mathrm{Rp}$ & $\mathrm{Rp}$ & $\mathrm{Rp}$ & $\mathrm{Rp}$ & $\mathrm{Rp}$ & $\mathrm{Rp}$ \\
\hline & 2 & & $\begin{array}{l}311.899 .45 \\
1,61\end{array}$ & & & $\begin{array}{l}311.899 .451, \\
61\end{array}$ & $\begin{array}{l}99.380 .777,3 \\
1\end{array}$ & $\begin{array}{l}10.079 .530 .9 \\
56,16\end{array}$ & $\begin{array}{l}3.211 .649 .19 \\
0,70\end{array}$ & $\begin{array}{l}9.767 .631 .50 \\
4,55\end{array}$ & $\begin{array}{l}3.112 .268 .41 \\
3,39\end{array}$ \\
\hline 13 & 0,2 & & $\mathrm{Rp}$ & & & $\mathrm{Rp}$ & $\mathrm{Rp}$ & $\mathrm{Rp}$ & $\mathrm{Rp}$ & $\mathrm{Rp}$ & $\mathrm{Rp}$ \\
\hline 15 & 0,2 & & $\mathrm{Rp}$ & $\mathrm{Rp}$ & & $\mathrm{Rp}$ & $\mathrm{Rp}$ & $\mathrm{Rp}$ & $\mathrm{Rp}$ & $\mathrm{Rp}$ & $\mathrm{Rp}$ \\
\hline & 4 & & $\begin{array}{l}340.820 .95 \\
2,06\end{array}$ & $\begin{array}{l}1.022 .462 .85 \\
6,17\end{array}$ & & $\begin{array}{l}1.363 .283 .80 \\
8,22\end{array}$ & $\begin{array}{l}326.359 .304, \\
72\end{array}$ & $\begin{array}{l}11.014 .175 .6 \\
23,13\end{array}$ & $\begin{array}{l}2.636 .706 .07 \\
4.53\end{array}$ & $\begin{array}{l}9.650 .891 .81 \\
4.91\end{array}$ & $\begin{array}{l}2.310 .346 .76 \\
9.81\end{array}$ \\
\hline 16 & $\begin{array}{c}0,2 \\
2\end{array}$ & & $\begin{array}{l}\mathrm{Rp} \\
351.045 .58 \\
0,62\end{array}$ & & & $\begin{array}{l}\mathrm{Rp} \\
351.045 .580 \\
62\end{array}$ & $\begin{array}{l}\mathrm{Rp} \\
76.397 .746,3 \\
3\end{array}$ & $\begin{array}{l}\mathrm{Rp} \\
11.344 .600 .8 \\
91,82\end{array}$ & $\begin{array}{l}\mathrm{Rp} \\
2.468 .915 .68 \\
7,97\end{array}$ & $\begin{array}{l}\mathrm{Rp} \\
10.993 .555 .3 \\
11,21\end{array}$ & $\begin{array}{l}\mathrm{Rp} \\
2.392 .517 .94 \\
1,64\end{array}$ \\
\hline
\end{tabular}


Table 20. Continue

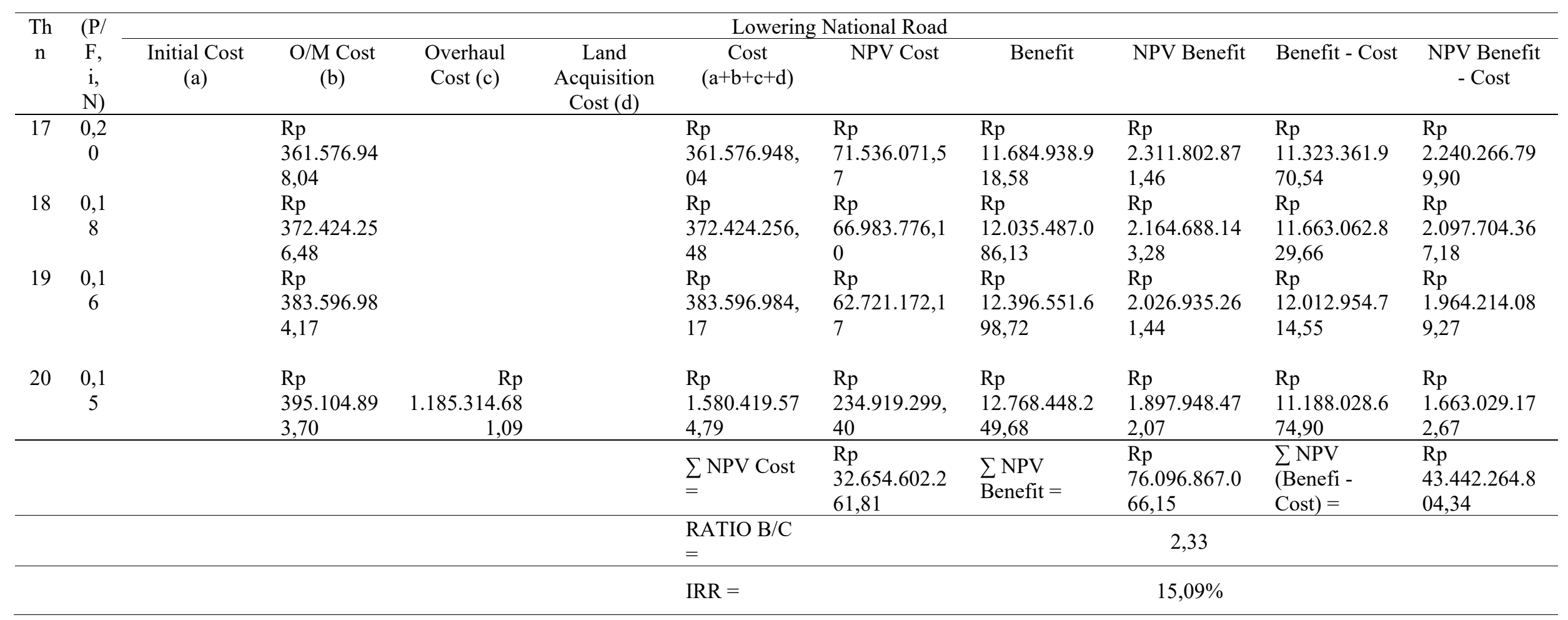


Table 21. Cash Flow BCR With Option for Lifting Bridge

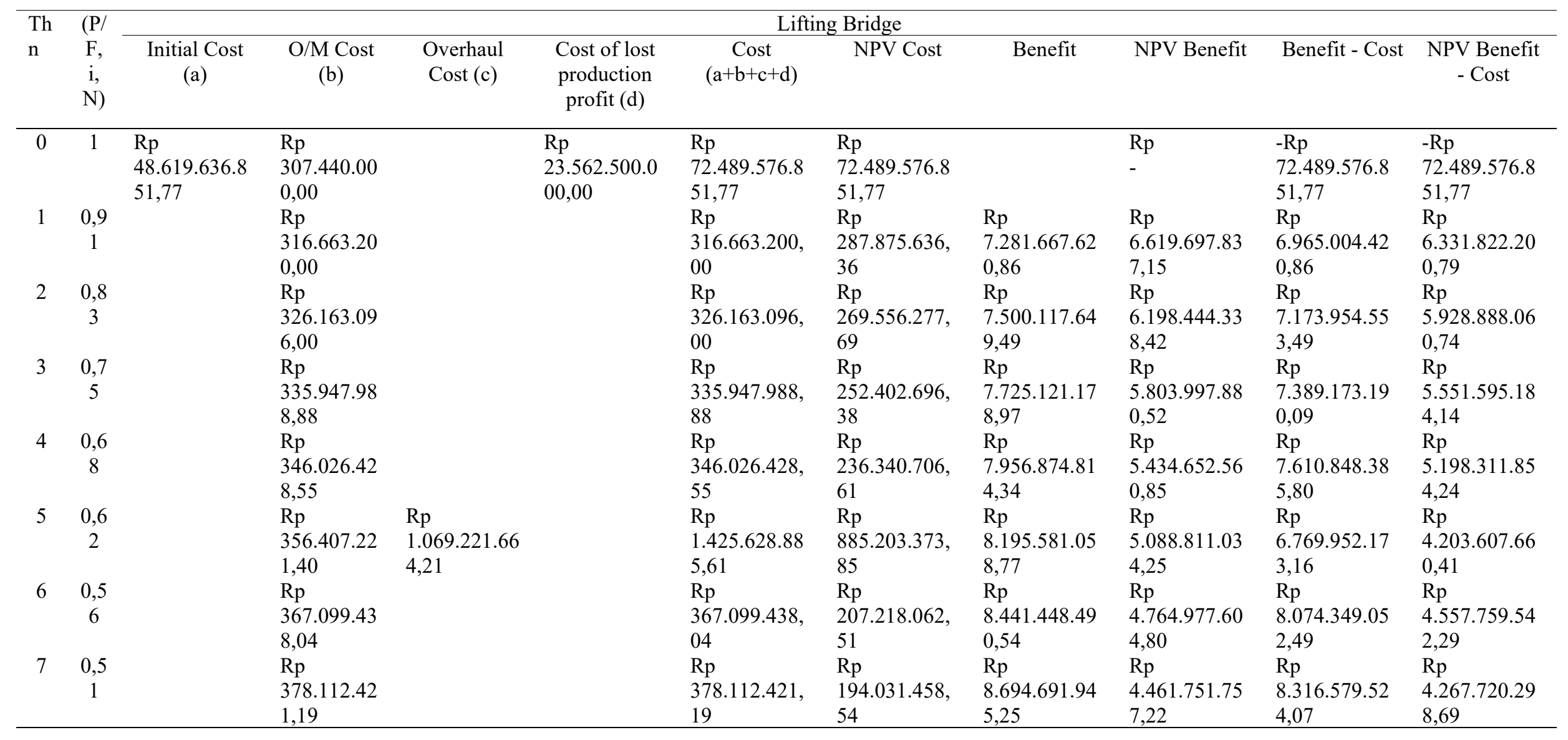


Table 21. Continue

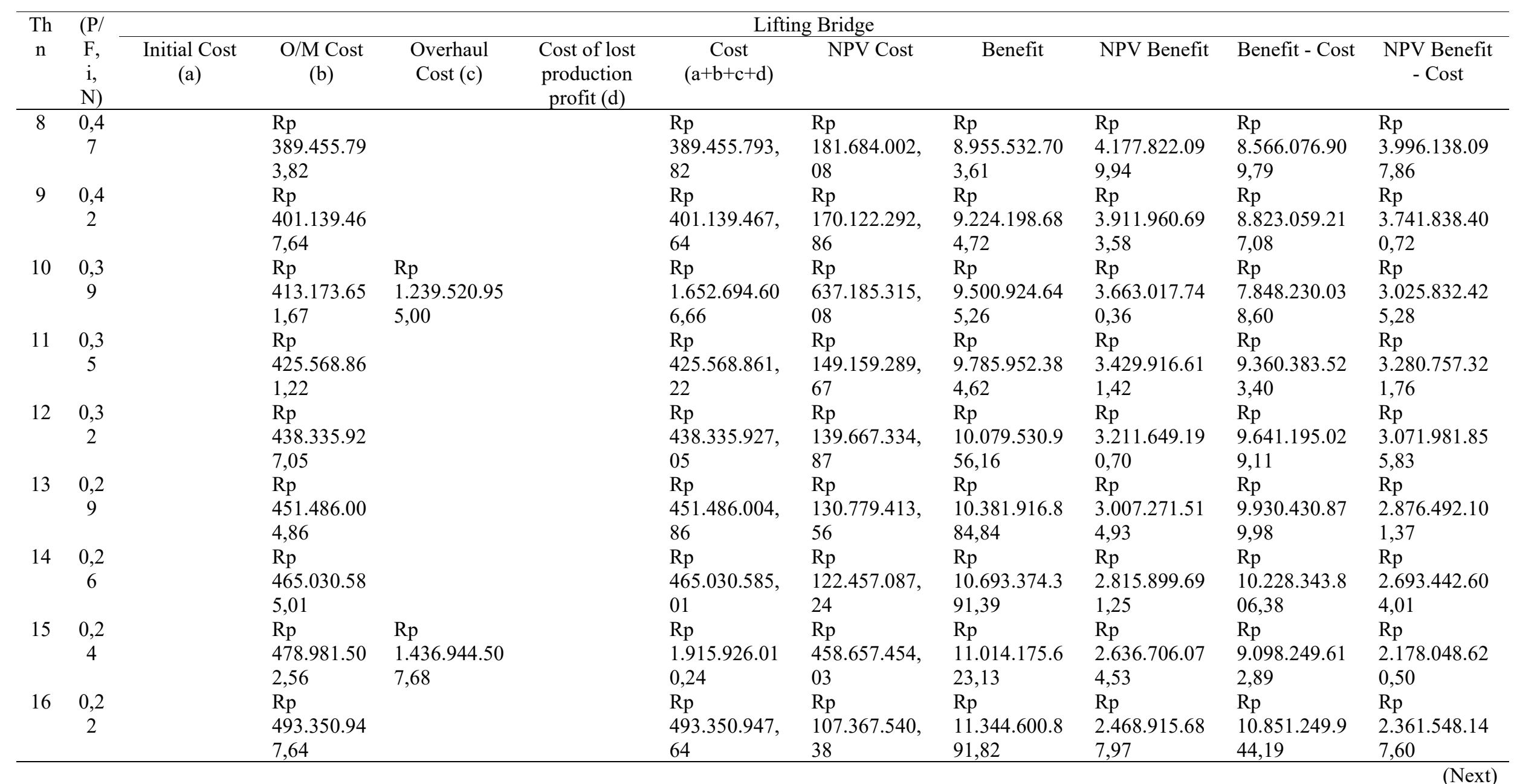


Table 21. Continue

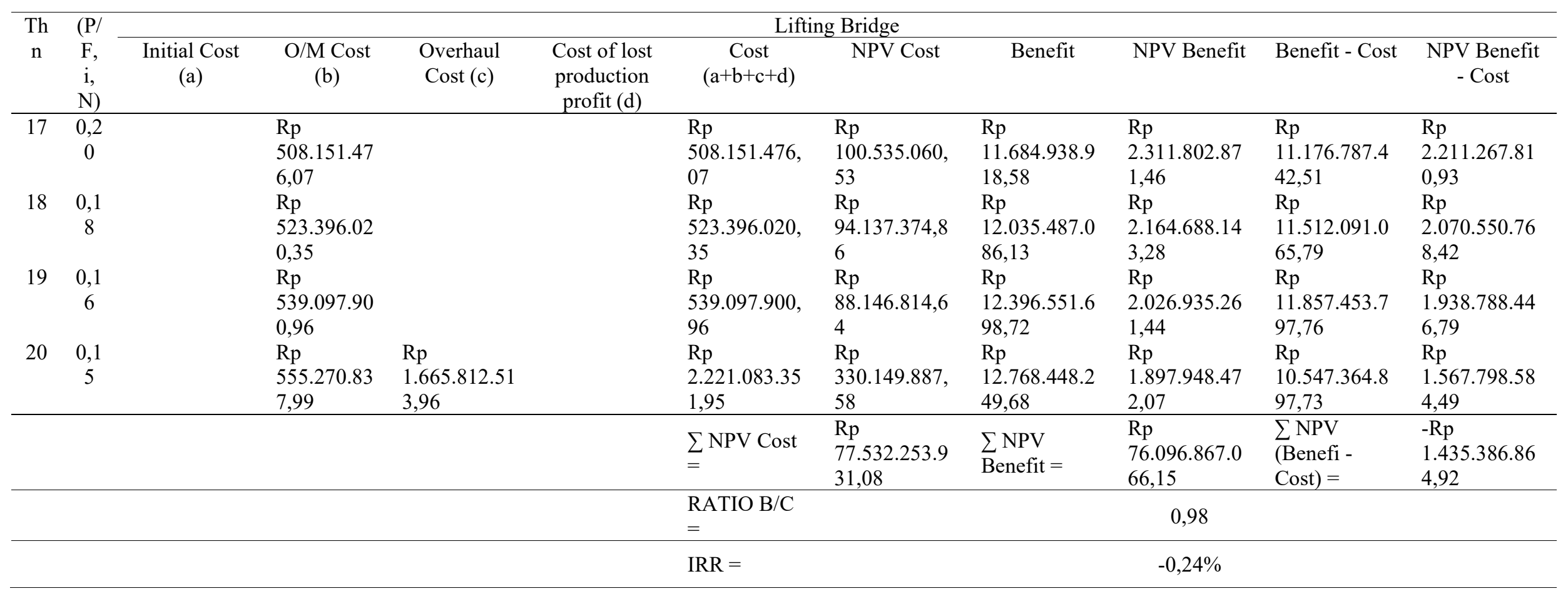




\subsection{Determination of Alternative Design for Vertical Clearance Under Tabalong Bridge}

The results of the AHP analysis show that the option chosen is the option of lowering the elevation of the national road rather than the option of increasing the elevation of the bridge's upper structure. Likewise with the results of the LCC/BCR analysis, the option chosen is the option of lowering the elevation of the national road rather than the option of increasing the elevation of the bridge's upper structure as shown in Table 22. The two analyzes mutually reinforce each other in making alternative selection decisions so that the option of lowering the elevation of the national road is the most appropriate alternative. precise, effective and efficient.

Table 22. Results of Determination of Design Alternatives

\begin{tabular}{cccc}
\hline & Purpose & \multicolumn{2}{c}{ Analysis Method } \\
\cline { 3 - 4 } & & $\begin{array}{c}\text { Non Financial } \\
\text { (AHP) }\end{array}$ & $\begin{array}{c}\text { Financial } \\
\text { (LCC/BCR) }\end{array}$ \\
\hline \multirow{2}{*}{$\overbrace{0}$} & $\begin{array}{c}\text { Lowering National } \\
\text { Road }\end{array}$ & Ok & Ok \\
\cline { 2 - 4 } & Lifting Bridge & Not Ok & Not Ok \\
\hline
\end{tabular}

\section{Conclusion}

From the results of research that has been done there are several things that can be concluded:

1. Based on the results of the Analytical Hierarchy Process (AHP) analysis for non-financial criteria, it was found that the determination of the best alternative design for the vertical clearance of the Tabalong Bridge is with option for lowering the elevation of the national road in terms of ease of construction, disruption to hauling operations, risk of construction failure, length of time for construction activities and disruption to the environment $\&$ society. The results of this analysis are shown by the synthesis value of the option for lowering the elevation of national roads by $85 \%$ and the option for increasing the elevation of the bridge's upper structure by $15 \%$ and the consistency ratio $(\mathrm{CR})$ of $0.05<0.1$. The consistency ratio below 0.1 indicates that the data from interviews and questionnaires from the respondents are consistent, so the AHP calculation does not need to be repeated. The option of increasing the elevation of the bridge's upper structure is technically difficult because the free space for the placement of piles between the Tabalong 1 Bridge (unloaded) and the Tabalong 2 Bridge (loaded) is very narrow and the stability of the superstructure of the bridge when it is above the hydraulic jack and must be lifted as high as \pm 1.1 $\mathrm{m}$.

2. Based on the analysis of Life Cycle Cost (LCC) and Benefit Cost Ratio (BCR) for financial criteria, it was found that the determination of the best alternative design for vertical clearance of the Tabalong Bridge is to perform the option for lowering the elevation of the national road where the LCC value is Rp. 44,877,651,669.27 more efficient than the option for increasing the elevation of the bridge's upper structure. Then the results of the Benefit Cost Ratio (BCR) analysis obtained the option for lowering the elevation of national roads with a BCR value of $2.33>1$ and NPV (benefit/cost) $=$ Rp. 43,442,264,804.34 >1 means that the option for lowering the elevation of national roads is feasible. While the bridge lifting option is obtained from the analysis of the value of BCR $=0.98<1$ and NPV (benefit/cost) $=-$ Rp. 1,435,386,864.92 $<1$ means that the option for increasing the elevation of the bridge's upper structure is not feasible.

3. From the two analysis results above, both AHP and LCC/BCC obtained the same alternative decision results and strengthens the justification in making decisions where the option for lowering the elevation of national roads is the most appropriate, effective and efficient alternative. From the results of interviews with related parties, the option for lowering the elevation of national roads has obtained permission from the road hall and can be implemented. 


\section{References}

Apriyanto, A. 2008. Perbandingan Kelayakan Jalan Beton dan Aspal dengan Metode Analytical Hierarchy Process (AHP). Semarang: Universitas Diponegoro.

Fify, H. 2002. Metode Pelaksanaan Pekerjaan Konstruksi Jembatan. ilmutekniksipil.com.

Hidayati, W., \& Harjanto, B. 2001. Konsep Dasar Penilaian Properti. Yogyakarta: Edisi Pertama, BPFE-Yogyakarta.

Kaufman, J. 2001. Value Management: Creating Competitive Advantage.

Kaufman, J. 2002. Manajemen Nilai. Jakarta: Prenhallindo.

Komite Penyusunan Standar Penilaian Indonesia. 2007. Standar Penilaian Indonesia. Jakarta: MAPPI.

Mintarsyah, H. 2012. Analisa Penggunaan Tertinggi dan Terbaik pada Lahan Bekas Terminal Sungailiat di Kabupaten Bangka. Tesis, Institut Teknologi Sepuluh Nopember, Surabaya.

Partovi, F. Y. 1994. Using the Analytic Hierarchy Process for ABC Analysis. International Journal of Operations \& Production Management.

Pembangunan, P. P. 2008. Buku Referensi untuk Kontraktor Bangunan Gedung dan Sipil.

Pujawan, I. N. 2004. Ekonomi Teknik. Surabaya: Edisi Pertama Cetakan Kedua, Guna Wijaya.

Saaty, T. L. 1993. Jakarta: PT. Pustaka Binaman Pressindo.

Saaty, T. L. 2001. Decision Making for Leaders Vo. II of the AHP Series.

Utomo Christiono, P. a. 2009. Value-based Group Decision on Support Bridge Selection. International Journal of Social, Behavioral, Educational, Economic, Business and Industrial Engineering.

Zahedi, F. 1986. The Analytic Hierarchy Process - A Survey of the Method and its Applications. Interfaces.

Nugroho, W. P. 2014. Analisa Biaya Pada Pemilihan Alternatif Alat Pemeliharaan Jalan di BBPJNV Surabaya Dengan Metode Life Cycle Cost. Tesis, Institut Teknologi Sepuluh Nopember, Surabaya.Saaty, T. L. 2001. Decision Making for Leaders Vo. II of the AHP Series.

Ridhawati, E. 2016. Penggunaan Analitical Hierarchy Process (AHP) Dalam Menentukan Prioritas Pengembangan Industri Kecil dan Menengah di Kecamatan Bandar Negeri Suoh Kabupaten Lampung Barat, Jurnal TAM (Technology Acceptance Model) Volume 6.

Chumaidi, M. 2017. Implementasi Value Based Decision Pada Pemilihan Metode Kerja Ereksi Girder Pada Pekerjaan Jembatan Kali Marmoyo Berdasarkan Kriteria Finansial dan Non - Finansial. Institut Teknologi Sepuluh Nopember, Surabaya.

Anwar, M. H. 2018. Penerapan Analitical Hierarchy Process (AHP) Dalam Penyusunan Skala Prioritas Untuk Menjaga Kinerja Saluran Irigasi (Studi Kasus Saluran Induk Mataram di D.I Yogyakarta. Universitas Muhammadiyah Surakarta, Surakarta.

Kementrian PUPR. 2017. Modul 3 Kelayakan Ekonomi. Bandung: Badan Pengembangan Sumber Daya Manusia Pusat Pendidikan dan Pelatihan Sumber Daya Air dan Konstruksi.

Kementerian PUPR. 2011. Peraturan Menteri Pekerjaan Umum Nomor 19/PRT/M/2011 tentang Persyaratan Teknis Jalan dan Kriteria Perencanaan Teknis Jalan. Jakarta.

Adaro Jasabara Indonesia. 2021. Laporan Review Study Comparison Raise Up Haul Road Bridge and Lowering National Road Adaro Indonesia. Jakarta.

Vanya, G. V. 2020. Analisis Penentuan Pondasi Jembatan Untuk Kemudahan Pelaksanaan di Lapangan Dengan Metode Rekayasa Nilai (Studi Kasus Pada Jembatan Sungai Temunih II Kecamatan Kusan Hulu Kabupaten Tanah Bumbu). Tesis, Universitas Lambung Mangkurat, Banjarmasin.

Bank Indonesia. 2021. Data Inflasi. https://www.bi.go.id/id/statistik/indikator/data-inflasi.aspx (diakses pada tanggal 6 Desember 2021).

Badan Pusat Statistik. 2021. Suku Bunga Kredit Rupiah Menurut Kelompok Bank 2020. https://www.bps.go.id/indicator/13/383/2/suku-bunga-kredit-rupiah menurut-kelompok-bank.html (diakses pada tanggal 6 Desember 2021). 